\title{
RESEARCH CENTER OF RADIOISOTOPES AT UNIVERSITY OF OSAKA PREFECTURE RADIOCARBON DATES I
}

\author{
SETSUKO SHIBATA, EIKO KAWANO and TAKESHIGE NAKABAYASHI
}

Research Center of Radioisotopes, Research Institute for Advanced Science and Technology, University of Osaka Prefecture, 1-2, Gakuen-cho, Sakai, Osaka, Japan

\section{INTRODUCTION}

The radiocarbon dating laboratory has been in operation since 1984 at the Radiation Center of Osaka Prefecture (OR), predecessor of the Research Center of Radioisotopes, University of Osaka Prefecture. We use liquid scintillation counting (LSC), following sample conversion to methanol through combustion and $\mathrm{LiAlH}_{4}$ reduction. This method was developed by Yamada et al. (Yamada, Higashimura and Shidei 1966; Yamada and Kobashigawa 1986). In cooperation with Yamada, we somewhat modified their procedure: 1) sample charcoal is burned at $700^{\circ} \mathrm{C}$ in the presence of $\mathrm{CuO}$ needles and Sulfix grains to remove sulfur and halogen compounds produced during the combustion; 2) the combustion is carried out by using $\mathrm{N}_{2}-\mathrm{O}_{2}$ mixed gas of minimized $\mathrm{O}_{2}$ content and stopped when a small amount of the charcoal still remains unchanged, because precise investigation of methanol preparation revealed that $\mathrm{O}_{2}$ gas stimulates byproduct formation during $\mathrm{LiAlH}_{4}$ reduction (Shibata et al. 1985; Shibata et al. 1993). Usually, methanol is prepared directly from sample charcoal in a reaction apparatus ("direct method"). When the sample quantity is insufficient, generated $\mathrm{CO}_{2}$ is isolated as $\mathrm{CaCO}_{3}$ and diluted with inactive commercial $\mathrm{CaCO}_{3}$ if necessary $\left(<40 \mathrm{~g}\right.$ of $\mathrm{CaCO}_{3}$ yield). Then $\mathrm{CaCO}_{3}$ is hydrolyzed with $\mathrm{HCl}$ to $\mathrm{CO}_{2}$ for methanol preparation in the usual way ("separate method"). We use standard oxalic acid SRM $4990 \mathrm{C}$ (HOxII) for determination of modern ${ }^{14} \mathrm{C}$ (Stuiver 1983). The acid is oxidized to $\mathrm{CO}_{2}$ using the wet method of Valastro, Land and Valera (1977) followed by methanol preparation in the same manner as for unknown samples.

Methanol obtained is purified and checked via gas chromatographic analysis prior to ${ }^{14} \mathrm{C}$ measure-

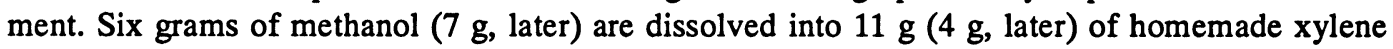
cocktail for LSC, using a Packard TRI-CARB ${ }^{\otimes} 460 \mathrm{CD}$ ). The counting efficiency is measured using a series of quenched standards close in composition to sample cocktails, while counting conditions are continually checked by measuring methanol prepared from contemporary rice grains as a secondary standard. Sample and background cocktails are alternatively measured for $100 \mathrm{~min}$ to attain desired statistical errors. We measure ${ }^{14} \mathrm{C}$ in HOxII for every batch of samples. The averaged value is $18.209 \pm 0.105 \mathrm{dpm} / \mathrm{gC}$ (one standard deviation, $1 \sigma$ ) for all measurements so far (11 times).

Smokeless coal was used for a blank test of methanol preparation and gave a ${ }^{14} \mathrm{C}$ date of $>35,000 \mathrm{yr}$ BP under routine conditions. As a control on our procedures, we ${ }^{14} \mathrm{C}$-dated several samples that had been dated by other laboratories. Our results were quite consistent with ${ }^{14} \mathrm{C}$ dates of other laboratories (Shibata et al. 1990).

Samples dated were wood, charcoal and peat. The quoted errors (at the $1 \sigma$ confidence level) include the standard deviations of count rates for unknown, background and modern samples. We report dates according to the guidelines of Stuiver and Polach (1977), i.e., in yr BP, based on the conventional Libby half-life for ${ }^{14} \mathrm{C}$ of $5568 \mathrm{yr}$. Correction for isotopic fractionation was not made. Calendar years shown in parentheses were age ranges $(2 \sigma)$ calculated by use of Method B (Probabilities) in the CALIB calibration program, Version. 3.3 (Stuiver and Reimer 1993). 


\section{ARCHAEOLOGICAL SAMPLES}

JAPAN

\section{Kankoji Series}

Kankoji site, Kanan-cho, Minamikawachi dist, Osaka pref $\left(34^{\circ} 2^{\prime} \mathrm{N}, 135^{\circ} 37^{\prime} \mathrm{E}\right), 102 \mathrm{~m}$ asl, is a typical upland village of Late Yayoi Age. Site was investigated by Educ Bd, Osaka pref. Collected and submitted 1985 by H. Otani, Educ Bd, Osaka Pref.

OR-5. KNJ-No. 1

Charcoal from hearth in rounded square ancient dwelling (sides 3.7 by $3.6 \mathrm{~m}$ ) No 1, located at the central part of Kankoji site (cal AD 147 to 591).

Comment (H.O.): Estimated as Late Yayoi Age. Result reasonable.

OR-9. KNJ-No. 2

$29,260 \pm 3860$

Wood from dark-gray clay layer, ca. $3 \mathrm{~m}$ deep, at northwest corner of Kanroji pond located at northeast edge of Kankoji site.

Comment: Separate method with $\mathrm{CaCO}_{3}$ dilution was used.

OR-6. KNJ-No. 3

$32,000 \pm 1810$

Wood from dark green-gray sandy clay layer, just under portion of OR-9.

OR-7. KNJ-No. 4

$>37800$

Wood from black-gray clay layer, ca. $4 \mathrm{~m}$ deep, at same place as OR-9.

\section{Shinpukuji Series}

Shinpukuji site, Mihara-cho, Minamikawachi dist, Osaka pref $\left(34^{\circ} 32^{\prime} \mathrm{N}, 135^{\circ} 33^{\prime} \mathrm{E}\right)$ includes remains of temple bell foundry, kilns and structures from Nara to Middle Age. Site was investigated 1984 to 1985 by joint Educ Bd, Osaka pref and Osaka ctr of Cultural Properties. Samples collected at kiln remain, $41 \mathrm{~m}$ asl, and submitted 1985 by A. Yamamoto, Osaka ctr of Cultural Properties.

OR-13. Sample No. 1

$1550 \pm 85$

Mixture of smashed charcoal and mud from tile-kiln No 2 (cal AD 344 to 658).

OR-23.

$1190 \pm 55$

Same sample as OR-13. Dated to confirm or correct date for OR-13, above (cal AD 706 to 979).

OR-17. Sample No. 2

$1380 \pm 190$

Mixture of smashed charcoal and mud from tile-kiln No 5 (cal AD 254 to 1024).

OR-15. Sample No. 5

$1540 \pm 60$

Mixture of smashed charcoal and mud from surroundings of tile-kilns No 2 and No 5 (cal AD 418 to 637).

OR-16. Sample No. 6

$1570 \pm 80$

Mixture of smashed charcoal and mud from same place as OR-15 (cal AD 270 to 649).

OR-14. Sample No. 10

$1410 \pm 65$

Mixture of smashed charcoal and mud from same place as OR-15 (cal AD 535 to 778).

OR-11. Sample No. 7

Charcoal from charcoal-kiln No 1 (cal AD 676 to 954).

$1230 \pm 55$ 
OR-12. Sample No. 9

$1450 \pm 55$

Charcoal from charcoal-kiln No 1 (cal AD 452 to 682).

Comment: Separate method was used for all samples in this series. Samples OR-13, -16 and -17 were diluted with inactive $\mathrm{CaCO}_{3}$. Tile kilns No 2 and No 5 est. as Nara Age (AY) and ${ }^{14} \mathrm{C}$ dates reasonable. Age of charcoal kiln No 1 was either AD 8 or 13 (AY). ${ }^{14} \mathrm{C}$ dates matched AD 8. Archaeological magnetic date for charcoal kiln No 1 (either AD 730 or 600 , H. Shibuya) was quite consistent with our results.

\section{Joyama Series}

Joyama site, Hirano Ward, Osaka city, Osaka pref $\left(34^{\circ} 36^{\prime} \mathrm{N}, 135^{\circ} 35^{\prime} \mathrm{E}\right), 10 \mathrm{~m}$ asl, includes many remains from Jomon to Modem Age. Site was investigated 1983 to 1985 by joint Educ Bd, Osaka Pref and Osaka Ctr of Cultural Properties. Samples were in Trench D, at $3 \mathrm{~m}$ depth. Collected 1984 to 1985 and submitted 1985 by S. Kanbayashi, Osaka ctr of Cultural Properties.

OR-18. SB0901W-11

$2190 \pm 60$

Fragments of burnt wood from rectangular ancient dwelling $5.7 \mathrm{~m}$ by $4.3 \mathrm{~m}, \mathrm{SB} 0901$. Associated with earthenware of Yayoi Age (cal 380 to 68 BC).

OR-19. SB1001W-4

$2200 \pm 80$

Fragments of burnt board from ancient dwelling (ca. $7 \mathrm{~m}$ in diam), SB1001. Associated with earthenware of Yayoi Age (cal 393 to $50 \mathrm{BC}$ ).

OR-19'.

$2080 \pm 60$

Same sample as OR-19. Re-dated at submitter's request to confirm or correct date for OR-19, above (cal $345 \mathrm{BC}$ to $\mathrm{AD} 71$ ).

OR-20. SB1001W-41

$1970 \pm 50$

Fragments of burnt wood from same dwelling as OR-19 (cal $66 \mathrm{BC}$ to $\mathrm{AD} 194)$.

OR-21. SB1004W-38

$2150 \pm 65$

Burnt stick wood from ancient dwelling (8.1-6.0 $\mathrm{m}$ in diam), SB1004. Associated with earthenware of Yayoi Age and a spindle wheel (cal $372 \mathrm{BC}$ to 10).

OR-22. SB1004W-14

$2090 \pm 75$

Burnt board wood from same dwelling as OR-21 (cal $357 \mathrm{BC}$ to AD 72).

Comment: Burnt materials such as grounds and woods were scattered throughout these ancient dwellings. These were estimated as fire-destroyed dwellings in Late Yayoi Age: dwelling SB0901 est. as middle part and dwellings SB1001 and SB1004 estimated as early part of Late Yayoi Age (SK). Sample for OR-22 was also dated by Kyoto Sangyo Univ (KSU). Result (1970 $\pm 20 \mathrm{BP}$, cal $150 \mathrm{BC}$ to $\mathrm{AD} 205$ ) agreed with our datum at $2 \sigma$ confidence level.

\section{Tai Series}

Tai site, Mihara-cho, Minamikawachi dist Osaka pref $\left(34^{\circ} 32^{\prime} 3^{\prime \prime} \mathrm{N}, 135^{\circ} 35^{\prime} 42^{\prime \prime} \mathrm{E}\right)$ is located at midpoint of terrace, ca. $39 \mathrm{~m}$ asl. Investigated 1986 by Osaka ctr of Cultural Properties. Collected and submitted 1986 by K. Kuninori.

OR-24. Driftwood 1

$31,110 \pm 1640$

Driftwood from bluish-green clay layer 12 , Trench $1 \mathrm{~A}$, at $2 \mathrm{~m}$ depth.

OR-25. Driftwood 2

$30,470 \pm 1520$

Driftwood from just under portion of OR-24. 


\section{Kosaka Series}

Kosaka site, Hirai, Sakai city, Osaka pref $\left(34^{\circ} 30^{\prime} 55^{\prime \prime} \mathrm{N}, 135^{\circ} 29^{\prime} 33^{\prime \prime} \mathrm{E}\right)$, at valley in northern extremity of Senboku Hill, 22-25 m asl, includes many remains from Jomon to Modern Age. Site was investigated 1985 to 1990 by joint Educ Bd, Osaka Pref and Osaka Ctr of Cultural Properties. Samples collected at $\mathrm{H}, \mathrm{F}$ and I dists.

\section{$H$ dist group}

H dist is located at bed of Hara Reservoir. Collected and submitted 1988 by K. Kuninori.

OR-58. Tree sample $A$

$2630 \pm 65$

Piece of tree from layer 12, Trench $1 \mathrm{H}$, at $1.5 \mathrm{~m}$ depth (cal $919 \mathrm{BC}$ to 530).

OR-59. Tree sample B

$2770 \pm 75$

Piece of tree sample same as OR-58 (cal 114 to $802 \mathrm{BC}$ ).

OR-60. Tree sample $C$

Piece of tree sample same as OR-58 (cal 1113 to 813 BC).

OR-61. Tree sample D

Piece of tree sample same as OR-58 (cal BC 1113 to 600).

OR-62. Peat No. 1

Peat from dark brown peat layer 13, Trench $1 \mathrm{H}$, just under portion of tree sample, above (cal 2140 to $1742 \mathrm{BC}$ ).

OR-63. Peat No. 2

Peat from same portion as OR-62 (cal 2031 to $1613 \mathrm{BC}$ ).

Comment: Final Jomon Age remains were found at just upper portion of tree sample for OR-58, -59, -60 and -61 . Samples were est. as before Final Jomon Age (KK). ${ }^{14} \mathrm{C}$ dates for tree sample corresponded to Late Jomon Age.

F dist group

Collected and submitted 1988 by K. Akaki, Senboku branch office, Osaka ctr of Cultural Properties.

OR-69. Water pipe 1

$1280 \pm 55$

Fragment of water pipe, $42 \mathrm{~cm}$ in diam $5.3 \mathrm{~m}$ long and 5-12 cm thick, from drain in layer 4 Trench 1 OF (cal AD 664 to 878).

OR-67. Driftwood 2

$1260 \pm 50$

Driftwood from same place as OR-69 (cal AD 672 to 883).

OR-68. Driftwood 3

$1270 \pm 55$

Driftwood from drain in layer 4 or 5, Trench 12F (cal AD 666 to 883).

Comment: Samples for OR-69 and -67 est. as Nara Age (KA) and sample for OR-68 estimated as before Kofun Age (KA). ${ }^{14} \mathrm{C}$ dates for these three samples corresponded to Nara Age. Portion including these samples was classified to old river 4 of Nara Age.

OR-64. Driftwood 8

$2460 \pm 65$

Driftwood from drain 3 in layer 4, Trench 16F (cal 768 to 405 BC).

OR-70. Driftwood 10

$2560 \pm 60$

Driftwood from valley-sand layer in Layer 4, Trench 16F (cal 820 to 424 BC). 
OR-73. Decayed plant 11

$2490 \pm 65$

Decayed plant from valley-humus layer in layer 4, Trench $16 \mathrm{~F}$ (cal 783 to $415 \mathrm{BC}$ ).

OR-82. Root 12

$3630 \pm 65$

Root, Trench 16F (cal 2182 to $1775 \mathrm{BC}$ ).

Comment: Sample for OR-64 est. as Kofun Age and samples for OR-70 and -73 est. as before Kofun Age (KA). ${ }^{14} \mathrm{C}$ dates for these samples corresponded to Late Jomon Age. They were assigned to period before Final Jomon Age.

OR-72. Board 7

$1510 \pm 110$

Board from base of layer 6, Trench 8F (cal AD 264 to 766).

OR-65. Root 6

$2570 \pm 50$

Root from same place as OR-72 (cal 818 to $526 \mathrm{BC}$ ).

OR-71. Root 5

Root from base of layer 6, Trench 9F. Associated with earthenware of Final Jomon Age (cal 917 to $546 \mathrm{BC})$.

Comment: Samples for OR-72, -65 and -71 est. as Final Jomon Age (KA). ${ }^{14} \mathrm{C}$ date for OR-72 was younger than Yayoi Age. Portion including sample for OR-72 was classified to Kofun Age river 6 Samples for OR-65 and -71 were assigned to periods before and just Final Jomon Age, respectively.

OR-66. Root 4

$3320 \pm 65$

Root from base of layer 6, Trench $11 \mathrm{~F}$ (cal 1738 to $1447 \mathrm{BC}$ ).

OR-74. Carbonized root 9

$3790 \pm 75$

Carbonized root from base of layer 6, Trench 12F (cal 2455 to 1984 BC).

\section{I dist group}

I dist is at flood plain located at left bank of Toki River. Samples collected at Trench 51 and submitted 1988 by K. Akaki.

OR-75. 1

$2350 \pm 45$

Peat from the highest peat layer in old river route (cal 534 to $210 \mathrm{BC}$ ).

OR-76. 2

$3390 \pm 70$

Peat from the second peat layer at same place as OR-75 (cal 1877 to $1517 \mathrm{BC}$ ).

OR-77. 3

$3800 \pm 70$

Peat from the third peat layer at same place as OR-75 (cal 2455 to $2034 \mathrm{BC}$ ).

OR-78. 4

$4490 \pm 70$

Peat from the fourth peat layer at same place as OR-75 (cal 3356 to $2926 \mathrm{BC}$ ).

OR-79. 6

$2500 \pm 65$

Peat from peat layer in another portion of the old river route, above (cal 791 to $417 \mathrm{BC}$ ).

OR-80. 7

$2600 \pm 75$

Piece of tree from peat layer in wetland behind the old river, above (cal 903 to $425 \mathrm{BC}$ ).

OR-81. 8

$2570 \pm 75$

Peat from peat layer including tree sample for OR-80 (cal 834 to $418 \mathrm{BC}$ ). 
OR-83. 5

$8990 \pm 230$

Peat from peat layer in natural levee of the old river route, above (cal 8522 to $7534 \mathrm{BC}$ ).

Comment: Sample for OR- 83 est. as before $500 \mathrm{BC}$ and others est. as between $500 \mathrm{BC}$ and $\mathrm{AD} 800$ (KA). ${ }^{14} \mathrm{C}$ date for OR-83 corresponded to Initial Jomon Age. ${ }^{14} \mathrm{C}$ dates for OR-75, $-76,-77,-78$ and -79 were dispersed during Middle to Final Jomon Age. These samples showed more and more low ${ }^{14} \mathrm{C}$ activity along with their depth, helping to determine start chronology at the area. The old river was named as Jomon River 28. Samples for OR-80 and -81 were classified as Final Jomon to early part of Yayoi Age.

SYRIA

OR-36.

$1060 \pm 55$

Chip of wood from ancient sunken ship found at bottom, $32 \mathrm{~m}$ deep, $2 \mathrm{~km}$ off coast of Tartous, Syria $\left(34^{\circ} 54^{\prime} \mathrm{N}, 35^{\circ} 51^{\prime} \mathrm{E}\right)$. Excavation was made (1985 to 1987 ) for research into maritime trade history in the Mediterranean jointly by the Directorate of Antiquities and Museums of the Syrian Arab Republic and the Syrian Coastal Archaeological Excavation Operation Committee of Japan. More than 5000 amphorae were found in the sunken ship (cal AD 879 to 1157).

Comment: Initially, amphorae est. as Greco-Roman period. ${ }^{14} \mathrm{C}$ date for OR-36 corresponded to period from 9th to 12th century. Age of the sunken ship was eventually determined to be the first half of 13 th century $\mathrm{AD}$ on the basis of heat luminescence date and ${ }^{14} \mathrm{C}$ dates by Nagoya University (Tandetron Accelerator Mass Spectrometry), in addition to our result.

\section{GEOLOGICAL SAMPLES}

JAPAN

\section{Buried Forest of Japan Cedar Series}

Japanese cedars (Cryptomeria japonica D. DON) buried under rice field, 50-80 cm deep, Mikatacho, Fukui pref $\left(35^{\circ} 31^{\prime} 50^{\prime \prime} \mathrm{N}, 135^{\circ} 53^{\prime} 22^{\prime \prime} \mathrm{E}\right), 20 \mathrm{~m}$ asl, were investigated and submitted 1986 by $\mathrm{H}$. Takahara, Osaka Agric Res Center (Kyoto pref Univ. For, since 1989).

OR-26. KR-W-1

$3390 \pm 55$

Chip of buried Japanese cedar, $35 \mathrm{~cm}$ in diam. There was a feeding-trace due to insects.

OR-28. KR-W-2

$3130 \pm 70$

Chip of buried Japanese cedar, $30 \mathrm{~cm}$ in diam and $6 \mathrm{~m}$ long. There were three feeding-traces due to insects.

Comment (HT): Feeding traces were recognized as larval tunnels of sugi bark borers, Semanotus japonicus Lacordaire (Coleoptera: Cerambycidae). Samples yielded first date when sugi bark borers had been inhabitant in Japan (Takahara, Ito and Takeoka 1988).

\section{Kigo and Yakumogahara Moors Series}

Samples from Kigo moor, Miyazu city, Kyoto pref $\left(35^{\circ} 40^{\prime} \mathrm{N}, 135^{\circ} 11^{\prime} \mathrm{E}\right)$, alt $550 \mathrm{~m}$, and from Yakumogahara moor, Shiga district, Shiga pref $\left(35^{\circ} 15^{\prime} 15^{\prime \prime} \mathrm{N}, 135^{\circ} 54^{\prime} 46^{\prime \prime} \mathrm{E}\right)$, alt $910 \mathrm{~m}$, were investigated and submitted 1987 by $\mathrm{H}$. Takahara.

OR-54. KG-46-58

Peat from Kigo moor, at $46-58 \mathrm{~cm}$ depth.

$910 \pm 100$ 
OR-27.

$14,760 \pm 220$

Peat from Kigo moor, at $520-530 \mathrm{~cm}$ depth.

OR-55. YK-B-47-55

$1050 \pm 90$

Peat from Yakumogahara moor, at $47-55 \mathrm{~cm}$ depth.

Comment: Separate method with $\mathrm{CaCO}_{3}$ dilution was used for OR-54 and -55 . Pollen analysis revealed that just upper portion of OR-54 or -55 corresponded to increasing period of pine tree forest at each region (HT). These ${ }^{14} \mathrm{C}$ dates helped determine beginning of natural forest destruction due to human activities, because pine tree forest tends to increase in parallel with destruction of the natural forest (HT). OR-27 est. age from 10,000 to 15,000 years $\mathrm{BP}$ and ${ }^{14} \mathrm{C}$ date was as expected.

\section{Koseinuma Moor Series}

Koseinuma moor, Yabu district, Hyogo pref. ( $\left.35^{\circ} 21^{\prime} \mathrm{N}, 134^{\circ} 31^{\prime} 09^{\prime \prime} \mathrm{E}\right)$, alt $1470 \mathrm{~m}$, is located in Japanese cedar forest near top of Mt. Hyonosen. Collected 1989 to 1991 and submitted by H. Takahara.

OR-107. KS-23-33

Peat from peat layer, $23-33 \mathrm{~cm}$ deep.

$780 \pm 75$

OR-108. KS-50-60

$1600 \pm 75$

Peat from same peat layer as OR-107, 50-60 cm deep.

OR-109. KS-85-95

$2380 \pm 60$

Peat from same peat layer as OR-107, $85-95 \mathrm{~cm}$ deep.

OR-97. KS89-II

$3450 \pm 90$

Peat from clayey peat layer at same place as OR-107, 108-118 cm deep.

Comment: Separate method with $\mathrm{CaCO}_{3}$ dilution was used for OR-107, -108 and -97 . Samples were measured to date changes in natural forests of Japanese cedar or pine tree at Mt. Hyonosen. ${ }^{14} \mathrm{C}$ activity for these peat samples decreased linearly along with their depth, implying constant speed of deposition at the area.

OR-110. IH-520-530

Peat, $520-530 \mathrm{~cm}$ deep, from Ikenotaira moor, Ichishi dist, Mie pref $\left(34^{\circ} 31^{\prime} 27^{\prime \prime} \mathrm{N}, 136^{\circ} 10^{\prime} 43^{\prime \prime} \mathrm{E}\right)$, alt $600 \mathrm{~m}$. Collected and submitted 1990 by H. Takahara.

Comment: Akahoya ash (ca. $6400 \mathrm{BP}$ ) was found at $264-271 \mathrm{~cm}$ depth and sample estimated as deposited during last glacial period (HT).

OR-94.

Peat, $1170-1200 \mathrm{~cm}$ deep, from Ukishimanomori moor, Shingu city, Wakayama pref $\left(33^{\circ} 43^{\prime} \mathrm{N}\right.$, $\left.135^{\circ} 59^{\prime} \mathrm{E}\right)$. Collected and submitted 1989 by M. Takeoka, Kyoto pref Univ.

Comment: Akahoya ash was found at $2000 \mathrm{~cm}$ depth and sample est. as 3000 to $4000 \mathrm{BP}$, whereas ${ }^{14} \mathrm{C}$ date was nearly modern (MT). Separate method with inactive $\mathrm{CaCO}_{3}$ dilution was used.

OR-95. KR-89-2

Peat, at $134-143 \mathrm{~cm}$ depth, from Karakemi moor, Kita-azumi dist, Nagano pref $\left(36^{\circ} 29^{\prime} 10^{\prime \prime} \mathrm{N}\right.$, $\left.137^{\circ} 53^{\prime} 35^{\prime \prime} \mathrm{E}\right)$, alt $945 \mathrm{~m}$, located in cold temperate zone of Shinshu area. Collected and submitted 1989 by M. Takeoka.

Comment: Sample was measured to date natural forest changes at inland area of Central Japan (TM). Separate method was used. 
OR-96. OG-89-3

$16,110 \pm 250$

Peat, at $180-190 \mathrm{~cm}$ depth, from Ohoawara moor, Ina dist, Nagano pref $\left(35^{\circ} 52^{\prime} 58^{\prime \prime} \mathrm{N}\right.$, $\left.138^{\circ} 10^{\prime} 53^{\prime \prime} \mathrm{E}\right)$, alt $1815 \mathrm{~m}$. Collected and submitted 1989 by M. Takeoka.

Comment: Sample was measured to date coniferous tree forest changes at subalpine zone in Central Japan (TM). Separate method was used.

OR-100. TIK-436.6-446.6

$2530 \pm 50$

Peat, at $436.6-446.6 \mathrm{~cm}$ depth, from Ikenotaira moor, Higashi-tonami dist, Toyama pref $\left(36^{\circ} 25^{\prime} \mathrm{N}\right.$, $\left.136^{\circ} 52^{\prime} 30^{\prime \prime} \mathrm{E}\right)$. Collected and submitted 1989 by M. Takeoka.

OR-101. NA-350-360

$1670 \pm 150$

Peat, at $350-360 \mathrm{~cm}$ depth, from Nawagaike moor, Tonami dist, Toyama pref $\left(36^{\circ} 28^{\prime} 30^{\prime \prime} \mathrm{N}\right.$, $136^{\circ} 56^{\prime} \mathrm{E}$ ), alt $810 \mathrm{~m}$. Collected and submitted 1990 by M. Takeoka.

Comment: Methanol yield was unexpectedly low due to bad sample contamination with soil. ${ }^{14} \mathrm{C}$ date was obtained by using corrected ${ }^{14} \mathrm{C}$ activities of crude methanol (97\% purity).

\section{Kaminokodaira Series}

Kaminokodaira, Nakashinkawa dist, Toyama pref $\left(36^{\circ} 34^{\prime} 6^{\prime \prime} \mathrm{N}, 137^{\circ} 30^{\prime} 31^{\prime \prime} \mathrm{E}\right)$. Collected and submitted 1990 by M. Takeoka.

OR-103. KA-I-35-41

$6580 \pm 65$

Peat, at $35-41 \mathrm{~cm}$ depth, alt $1410 \mathrm{~m}$.

OR-104. KA-II-60-66

$1240 \pm 40$

Peat, at $60-66 \mathrm{~cm}$ depth, alt $1425 \mathrm{~m}$.

OR-102. KA-II-90-94

$10,960 \pm 300$

Peat, at $90-94 \mathrm{~cm}$ depth, from same place as OR-104.

Comment: ${ }^{14} \mathrm{C}$ date for OR-102 was determined by using corrected ${ }^{14} \mathrm{C}$ activity of crude methanol (98\% purity) because of unexpectedly low yield of methanol due to bad sample contamination with soil. Separate method was used for OR-103 and -104.

\section{BORNEO}

\section{South Kalimantan Series}

Peat from swamp in South Kalimantan, Bomeo $\left(3^{\circ} 7^{\prime} \mathrm{S}, 114^{\circ} 30^{\prime} \mathrm{E}\right)$. Collected and submitted 1986 by H. Furukawa, Center for Southeast Asian Studies, Kyoto University.

OR-39. BM41

$1420 \pm 70$

Peat, $25-75 \mathrm{~cm}$ deep.

OR-40. BM41

$2000 \pm 50$

Peat, $150-194 \mathrm{~cm}$ deep.

\section{SUMATRA}

\section{Pulan Kijang Series}

Samples from swamp in Jambi $\left(0^{\circ} 45^{\prime} \mathrm{S}, 103^{\circ} 15^{\prime} \mathrm{E}\right)$. Collected and submitted 1986 by H. Furukawa.

OR-41. Pulan Kijang 4

$760 \pm 65$

Peat, $30-50 \mathrm{~cm}$ deep. 
OR-42. Pulan Kijang 4

$1040 \pm 50$

Peat, $100-120 \mathrm{~cm}$ deep.

OR-43. Pulan Kijang 4

Peat, $180-200 \mathrm{~cm}$ deep.

$1550 \pm 60$

\section{Dendang Series}

Samples from swamp in Jambi $\left(1^{\circ} 10^{\prime} \mathrm{S}, 103^{\circ} 50^{\prime} \mathrm{E}\right)$. Collected and submitted 1986 by H. Furukawa.

OR-44. Dendang Unit II

$1120 \pm 55$

Peat, $30-50 \mathrm{~cm}$ deep.

OR-45. Dendang Unit ll

$1440 \pm 55$

Peat, $100-120 \mathrm{~cm}$ deep.

OR-46. SK19 (Pelita)

Peat, $30-50 \mathrm{~cm}$ deep, from swamp in Jambi $\left(1^{\circ} 06^{\prime} \mathrm{S}, 104^{\circ} 04^{\prime} \mathrm{E}\right)$. Collected and submitted 1986 by

H. Furukawa.

\section{REFERENCES}

Shibata, S., Kawano, E., Nakabayashi, T., Kawamura, S. and Yamada, O. 1985 Estimation of low level carbon14 in environment: Methanol synthesis from rice grains and liquid scintillation counting. Annual Report of the Radiation Center of Osaka 26: 115-121.

Shibata, S., Kawano, E., Nakabayashi, T., Kawamura, S. and Yamada, O. 1990 Radiocarbon dating by Methanol-LSC method. Annual Report of the Radiation Center of Osaka 30: 83-90.

Shibata, S., Kawano, E., Nakabayashi, T. and Yamada, O. 1993 Additional study of the direct Methanol-LSC method for low-level ${ }^{14} \mathrm{C}$ measurement. Applied Radiation and Isotopes 44: 1491-1493.

Stuiver, M. and Polach, H. A. 1977 Discussion: Reporting of ${ }^{14} \mathrm{C}$ data. Radiocarbon 19(3): 355-363.

Stuiver, M. 1983 International agreements and the use of the new oxalic acid standard. In Stuiver, M. and Kra. R. S., eds. Proceedings of the 11 th International ${ }^{14} \mathrm{C}$
Conference. Radiocarbon 25(2): 793-795.

Stuiver, M. and Reimer, P. J. 1993 Extended ${ }^{14} \mathrm{C}$ data base and revised Calib. 3.0. ${ }^{14} \mathrm{C}$ age cal ibration program. In Stuiver, M., Long, A. and Kra, R. S., eds., Calibration Issue. Radiocarbon 35(1) 215-230.

Takahara, H., Ito, T. and Takeoka, M. 1988 Woods invaded by the sugi bark borer, Semanotus japonicus $\mathrm{La}$ cordaire (Coleoptera: Cerambycidae), about 3000 years ago, and the forest vegetation at that time. Journal of the Japanese Forestry Society 70: 143-150.

Valastro, S., Jr., Land, L. S. and Varela, A. G. 1977 An improved procedure for wet oxidation of the ${ }^{14} \mathrm{C}$ NBS oxalic acid standard. Radiocarbon 19: 375-382.

Yamada, O., Higashimura, T. and Shidei, T. $1966{ }^{14} \mathrm{C}$ dating by liquid scintillation counting. Radioisotopes 15(2): 73-76.

Yamada, O. and Kobashigawa, A. 1986 KSU Radiocarbon dates 1. Radiocarbon 28(3): 1077-1101. 